ACCEPTED MANUSCRIPT • OPEN ACCESS

\title{
Modulated molecular markers of restenosis and thrombosis by in-vitro vascular cells exposed to bioresorbable scaffolds
}

To cite this article before publication: Federico Vozzi et al 2021 Biomed. Mater. in press https://doi.org/10.1088/1748-605X/ac0401

\section{Manuscript version: Accepted Manuscript}

Accepted Manuscript is "the version of the article accepted for publication including all changes made as a result of the peer review process, and which may also include the addition to the article by IOP Publishing of a header, an article ID, a cover sheet and/or an 'Accepted Manuscript' watermark, but excluding any other editing, typesetting or other changes made by IOP Publishing and/or its licensors"

This Accepted Manuscript is @ 2021 The Author(s). Published by IOP Publishing Ltd.

As the Version of Record of this article is going to be / has been published on a gold open access basis under a CC BY 3.0 licence, this Accepted Manuscript is available for reuse under a CC BY 3.0 licence immediately.

Everyone is permitted to use all or part of the original content in this article, provided that they adhere to all the terms of the licence https://creativecommons.org/licences/by/3.0

Although reasonable endeavours have been taken to obtain all necessary permissions from third parties to include their copyrighted content within this article, their full citation and copyright line may not be present in this Accepted Manuscript version. Before using any content from this article, please refer to the Version of Record on IOPscience once published for full citation and copyright details, as permissions may be required. All third party content is fully copyright protected and is not published on a gold open access basis under a CC BY licence, unless that is specifically stated in the figure caption in the Version of Record.

View the article online for updates and enhancements. 


\section{MODULATED MOLECULAR MARKERS OF RESTENOSIS AND THROMBOSIS BY IN-VITRO VASCULAR CELLS EXPOSED TO BIORESORBABLE SCAFFOLDS}

Vozzi F ${ }^{1}$, Cecchettini $\mathrm{A}^{1,2}$, Cabiati $\mathrm{M}^{1}$, Fornaro $\mathrm{MG}^{1}$, Aretini $\mathrm{P}^{3}$, Del Ry $\mathrm{S}^{1}$, Rocchiccioli $\mathrm{S}^{1}$, Pelosi G MD

${ }^{1}$ Institute of Clinical Physiology IFC-CNR, Via Giuseppe Moruzzi 1, Pisa, Italy

${ }^{2}$ Department of Clinical and Experimental Medicine, University of Pisa, Via Volta 4, Pisa, Italy

${ }^{3}$ Fondazione Pisana per la Scienza ONLUS, Via Ferruccio Giovannini, 13, San Giuliano Terme, Italy

\section{Corresponding author}

Federico Vozzi

CNR Institute of Clinical Physiology

Via Giuseppe Moruzzi 1, 56124 Pisa - Italy

Tel: 0503152672 - Fax: 0503152166

e-mail: vozzi@ifc.cnr.it

Received xxxxxx

Accepted for publication $\mathrm{xxxxxx}$

Published xxxxxx 


\section{Introduction}

Atherosclerosis, from the early development of fatty streaks to classic atheroma and advanced plaques formation, is the common pathology underlying major adverse events such as myocardial infarction and stroke. The acute rupture or erosion of a plaque may cause local thrombosis, leading to partial or total occlusion of the affected artery [1]. Among the available treatment techniques, percutaneous invasive interventions (PCIs), including coronary angioplasty and stent implantation, represent the leading choice. The advent of coronary stents resulted in reduction of procedure-related complications and markedly improved the long-term outcomes [2]. Nowadays, the majority of PCI procedures include the utilization of coronary stents and Interventional Cardiologists are faced with a wide spectrum of coronary stent types, from early conventional stents as Bare-Metal Stent (BMS) to Drug-Eluting Stent (DES), commonly used in current practice, followed by the new Bioresorbable Vascular Scaffold (BVS) stents. The evolution from BMS to DES produced a significant decrease in the frequency of major PCI complications, namely In-Stent Restenosis (ISR) and Stent Thrombosis (ST). PCI with BVS has emerged as an alternative since the presence of the prosthesis in the coronary artery is temporary [3]. This technology enables restoration of the normal vasomotor tone and allows positive remodeling, simultaneously reducing inflammation and facilitating further interventions by percutaneous or surgical means [4]. In this action of recoyery a support is obtained by the use of specific drugs, as everolimus, which is an inhibitor of mammalian target of rapamycin (mTOR) and are currently used as an immunosuppressant to prevent rejection of organ transplants. This drug has an anti-proliferative effect inhhibting Vascular Smooth Muscle Cells (VMSC) proliferation via blocking the cell cycle in the G1 phase [5], and has showed an antiinflammatory effect in neutrophils reducing the release of IL8 and decreasing TNF- $\alpha$-induced adhesion of neutrophils to Endothelial Cells (ECs) [6]. Despite expectations, clinical trials have registered a higher incidence of ST [7] and also ISR [8] following bioresorbable vascular scaffolds (BVS, Abbott Vascular). Likewise coronary atherosclerosis development and progression, also this so-called "stent disease" is a nonlinear, complex process, which follows different stages and involves several cell types and dynamic dys-regulations in biomolecular networks $[9,10]$. For early prediction and prevention, it is critical to identify pre-disease molecular markers. VSMC and EC have leading roles in ISR and ST. Endothelial denudation and dysfunction are involved in vascular remodeling, thrombus formation and VSMCs activation. ECs synthesize several growth factors, including FGF, PDGF, TGF-beta as well as heparin and other growthinhibitory factors that are important in SMC proliferation [11]. Normally quiescent VSMCs de-differentiate to a proliferative activated phenotype in response to endothelial injury. Activated VSMCs migrate to the intimal space, synthetize and secret large amounts of ECM, especially collagen and fibronectin, together with matrix metalloproteinases (MMP-1 and MMP-3) [12-14]. Multiple growth factors and cytokines 
(PGDF, Interleukins, TNF-a, VEGF, monocyte chemoattractant protein-1 (MCP-1)) are involved in ISR [15]. Moreover, it is well-known since a long time ago that $\mathrm{ECM} /$ integrin/focal adhesion pathway is important for the regulation of VSMC gene transcription, in response to the mechanical factors that are significant in arteries, subjected to shear stress due to blood pressure [16,17]. Flow driven mechanosensing pathways can alter endothelial phenotype and causes the production of cellular adhesion molecules, proinflammatory cytokines and transcription factors [18].

The aim of this work is focused on the investigation, through an in-vitro fluid dynamic model, of the gene expression in human vascular cells Human Coronary Artery Smooth Muscle cells (HCASMCs) and Human Coronary Artery Endothelial cells (HCAECs) exposed to physiological or pathological shear stress after application of BVS and Everolimus, to highlight potential markers associated with restenosis and/or thrombosis.

Human coronary primary vascular cells (Vascular Smooth Muscle Cells - HCASMCs, Endothelial Cells - HCAECs) were cultured in static and dynamic conditions (shear stress of 1 and 20 dyne $/ \mathrm{cm} 2$ ) with and without BVS and drug. RNA was isolated and the transcriptomic profile was analyzed. Comparing different cell culture conditions and with the support of Gene Ontology (GO) and network enhancing analysis, a group of genes were highlighted.

Among these, we focused on MEOX2, SEMA3E, BMP4, HMOX-1 and SELE for their involvement in different aspects of vascular injury and arterial wall homeostasis.

MEOX2, SEMA3E and HMOX-1 have all protective effects against the progression of atherosclerosis. MEOX2 is a transcription factor known to regulate proliferation and differentiation of vascular SMC and EC [19] and these mechanisms play key roles in cardiovascular diseases[20] SEMA3E interferes with the process of neointimal formation, blocking VSMC migration and proliferation [21]. HMOX-1 depletion in animal model was shown to accelerate atherosclerosis and its influence is due to the degradation of pro-oxidant heme and the generation of anti-oxidant products [22].

BMP4 is an inflammatory mechanosensitive cytokine and its expression is enhanced by disturbed shear stress in ECs. BMP4 triggers an inflammatory cascade involving ICAM-1 that in turn allows monocyte recruitment, foam cell lesion formation and thus atherosclerotic plaque onset [23].

Also, E-selectin (SELE) is produced by ECs; it is an adhesion molecule and a specific marker of endothelial dysfunction regulating the extravasion of leukocytes towards the sites of inflammation. VSMCs seem to induce its expression in the adjacent ECs while shear stress (12 dynes/cm2) inhibits it [24]. This study shows how data integration approaches based on transcriptomic techniques could facilitate the identification novel disease markers and molecular targets to be used for prevention and early diagnosis $[25,26]$.

\section{Method}

\subsection{Cell cultures}

Primary cells were recovered from healthy subjects. Primary human coronary artery endothelial cells (HCAECs) were purchased from Promocell $\mathrm{GmbH}$ (Heidelberg, Germany) and cultured in the manufacturer's recommended medium, the Endothelial Cell Growth Basal Medium MV2 supplemented with Growth Medium MV2 Supplement Pack. Primary human coronary artery smooth muscle cells (HCASMCs) were purchased from Thermo Scientific (Waltham, MA, USA) and cultured in the manufacturer's recommended medium, the Medium 231 supplemented with Smooth Muscle Growth Supplement.

\subsection{Cell imaging}

For cell characterization by immunofluorescence, cells were washed with PBS, fixed with a $5 \%$ formalin solution in PBS for 20 minutes at room temperature (RT) and stored at $4^{\circ} \mathrm{C}$ in PBS. Cells, after fixation, were placed in contact with $0.1 \%$ Triton X-100 in PBS at RT for 3-5 minutes to permeabilize cell membranes. Triton solution was removed and 5\% BSA in PBS $1 \mathrm{X}$ for 30 minutes to block non-specific binding. In order to highlight cell structure a solution of TRITC-Phalloidin (Elabscience, Houston, TX, USA) diluted $1: 200$ in $1 \%$ BSA was added and incubated in the dark at RT for 1 hour. At the end of the protocol, an anti-fade solution, supplemented with DAPI (4' 6- diamidino-2-phenylindole, Sigma-Aldrich, St. Louis, MO, USA), useful to mark cell nuclei, was added.

\subsection{Everolimus cytotoxicity}

A range of concentrations (1-2000 nM) was tested on both HCAECs and HCASMCs. Cells (8000 cells/well) were seeded in a 96-well plate and cultured with $100 \mu$ l of drugsupplemented media for 6 and 24 hours. At the end of each experimental time, cells were tested with CellTiter-Blue ${ }^{\circledR}$ Cell Viability Fluorometric Assay (Promega, Madison, USA). After 2,5 h of incubation, the fluorescence signal was detected with a microplate reader (BMG Labtech, Ortenberg, Germany).

\subsection{Dynamic flow tests}

HCAECs and HCASMCs, within the 2nd and 6th passages, were used. When at confluence, cells detached with $0.5 \%$ Trypsin in $0.5 \mathrm{mM}$ EDTA (Sigma-Aldrich, St. Louis, MO, USA), and seeded (50000 cells/ $\mu$-Slide) in Ibidi $\mathrm{GmbH} \mu$ Slide I Luer $0.4 \mathrm{~mm}$ (Gräfelfing, Germany). The BVS was a 
Polylactic acid (PLLA) prototype furnished by Boston Scientific (Galway, Ireland): it has a length of $16 \mathrm{~mm}$, an internal diameter of $3 \mathrm{~mm}$, and strut thickness of $105 \mu \mathrm{m}$ (Figure 1S, see Supplementary file).

In BVS experiments, scaffolds were placed over a polymeric coverslip stuck to Ibidi sticky-Slide I Luer flow system, a bottomless channel slide with a self-adhesive underside. Everolimus (Sigma-Aldrich, St. Louis, MO, USA) was directly dissolved into the medium at a fixed concentration of $600 \mathrm{nM}$ (consistent with data obtained by cytotoxicity tests and literature) [27] to ensure reproducible results. Every experiment lasted 6 hours. The experiments were conducted under 1 or $20 \mathrm{dyne} / \mathrm{cm}^{2}$ ).

\subsection{RNA extraction}

Total RNA was extracted from cells by a dedicated kit (RNeasy Plus Micro Kit, Qiagen Spa, Milano, Italy) accurately modified to purify total RNA (including miRNA) from small amounts of cells $\left(<5^{*} 10^{\wedge} 5\right)$; after re-suspension and lysis of the cells in a highly denaturing guanidineisothiocyanate-containing buffer, samples were selective passed through a gDNA Eliminator spin column. Ethanol was added to the flow-through to provide appropriate binding conditions for RNA, and the samples were then applied to a silica-based membrane (RNeasy MinElute spin column), speeded on a microspin centrifuge; specific buffers allowed RNA to bind to the RNeasy silica-membrane and contaminants were efficiently washed away. High-quality RNA was then eluted in $14 \mu \mathrm{l}$ of RNAse free water without the need for additional DNase digestion.

The total RNA samples concentration was determined by measuring the absorbance at 260 and $280 \mathrm{~nm}$ (NanoDrop Thermofisher, Waltham, MA, USA) and calculated using the Beer-Lambert law (expected values between 1.8-2.1).

\subsection{Transcriptome analysis for discovery and gene expression}

Ovation SoLo RNA-seq Library Preparation kit (NuGEN, Redwood City, CA) has been used for library preparation following the manufacturer's instructions (library type: frsecond strand). RNA samples were quantified and quality tested by Agilent 2100 Bioanalyzer RNA assay (Agilent Technologies, Santa Clara, CA) or Caliper (PerkinElmer, Waltham, MA). Final libraries were checked with both Qubit 2.0 Fluorometer (Invitrogen, Carlsbad, CA) and Agilent Bioanalyzer DNA assay or Caliper (PerkinElmer, Waltham, MA). Libraries were then prepared for sequencing and sequenced on single-end 75 bp mode on NextSeq 500 (Illumina, San Diego, CA), ensuring 30 million reads per sample.

\subsection{Bioinformatics analysis}

Six groups of experiments for each cell type were considered for differential analysis of gene expression data, as summarized in Table 1.

\begin{tabular}{|c|c|c|}
\hline Group & Experiments & Objective \\
\hline 1 & Static set up & $\begin{array}{c}\text { In-vitro standard static } \\
\text { condition }\end{array}$ \\
\hline 2 & $\begin{array}{l}\text { Dynamic set up } \\
\left(1 \text { dyne } / \mathrm{cm}^{2}\right)\end{array}$ & In-vitro hemodynamic \\
\hline 3 & $\begin{array}{l}\text { Dynamic set up } \\
\left(20 \text { dyne } / \mathrm{cm}^{2}\right)\end{array}$ & reference standard \\
\hline 4 & $\begin{array}{l}\text { Static set up - } \\
\text { BVS+Drug }\end{array}$ & $\begin{array}{l}\text { In-vitro standard static } \\
\text { condition with application } \\
\text { of BVS+Drug }\end{array}$ \\
\hline 5 & $\begin{array}{l}\text { Dynamic set up } \\
\left(1 \mathrm{dyne} / \mathrm{cm}^{2}\right)- \\
\text { BVS+Drug }\end{array}$ & In-vitro model of stented \\
\hline 6 & $\begin{array}{c}\text { Dynamic set up } \\
\left(20 \text { dyne } / \mathrm{cm}^{2}\right)- \\
\text { BVS+Drug }\end{array}$ & hemodynamic \\
\hline
\end{tabular}

Table 1. Experimental conditions. Each group indicates the hemodynamic condition of in-vitro experiments performed with HCAECs and HCASMCs.

For bioinformatics analysis, a case calling and demultiplexing was performed processing raw data for both format conversion and demultiplexing by the Bcl2Fastq 2.20 version of the Illumina pipeline. Then, a trimming and deduplication process was done, removing lower quality bases and adapters by ERNE and Cutadapt software. Reads deduplication based on the unique molecular identifier (UMI) composed of 8 random bases for unambiguous identification of unique library molecules by IGATech (Udine, Italy) proprietary script were used to discriminate between true PCR duplicates and independent adaptor ligation events to fragments with the same start site. Alignments on the reference genome GRCh38 were performed with STAR using a two-pass method. The transcripts count was executed, assembling, and quantifying the full-length transcripts, which represented multiple spliced variants for each gene locus by Stringtie. DESeq2 was used to perform comparisons between expression levels of genes and transcripts. Normalization was performed using the median-of-ratios method [28]. An initial list of modulated genes in the current experimental set was determined by application of a likelihood ratio test [29] accounting for the model "cell-type + flow + stent + stent:flow", which was reduced by the variance accounted for "cell-type" only. Adjusted p-value $<0.01$ was set an initial threshold. Further analyses on pairwise comparison were obtained by filtration of the Fold Change (FC) calculation: the ratios between the relative expression values of two different conditions, expressed as absolute value, was assessed to be 
above 3. The transcriptomic data were submitted to the Gene Expression Omnibus (GEO) under accession no. GSE139292.

For the Gene Ontology (GO) analysis, focused on gene association to specific biological processes, the Genemania web application was used (https://genemania.org/).

For the network enhancing process, miRNET system (https://www.mirnet.ca/miRNet/home.xhtml), an easy-to-use, web-based platform designed to help elucidate microRNA (miRNA) and trascription factos (TF) functions by integrating users' data with existing knowledge via network-based visual analytics [30], was used.

\section{Results}

\subsection{Cell characterization}

HCAECs and HCMASCs were observed under fluorescent microscopy in order to observe the cell morphology under the different experimental conditions. In Fig. $2 \mathrm{~S}$ (see Sumpplementary file), the presence of BVS+Drug in HCAECs seems to better preserve, at $1 \mathrm{dyne} / \mathrm{cm}^{2}$, cytoskeletal structure and morphology, porbably due to the physical presence of BVS that contrast and protect against the turbulent flow. At $20 \mathrm{dyne} / \mathrm{cm}^{2}, \mathrm{ECs}$, as expected, present a more elongated shape with cytoskeletal fibers aligned to the flow (Figure 2S-c and d). For HCASMCs (Figure 3S, see Supplementary file), at $20 \mathrm{dyne} / \mathrm{cm}^{2}$, both with and wihtout BVS+Drug (Figure 3S-c and d), cells seems to loose the typical spindle-shape morphology acquiring a more polygonal structure, related with an activated and sytnthetic state [12]. At 1 dyne $/ \mathrm{cm}^{2}$ with BVS+Drug (Figure 3S-b), we can observe a dysregulation of cytoskeletal organization respect to the cells without (Figure 3S-a).

\subsection{Everolimus cytotoxicity}

Cytotoxicity analysis showed that, for the concentration range explored (1-2000 nM Everolimus), cell viability was preserved above $80 \%$ within 24 hours and no significant differences were observed between the two cell types and the two-time intervals chosen (6 and 24 hours) (Figure 1a and 1b).

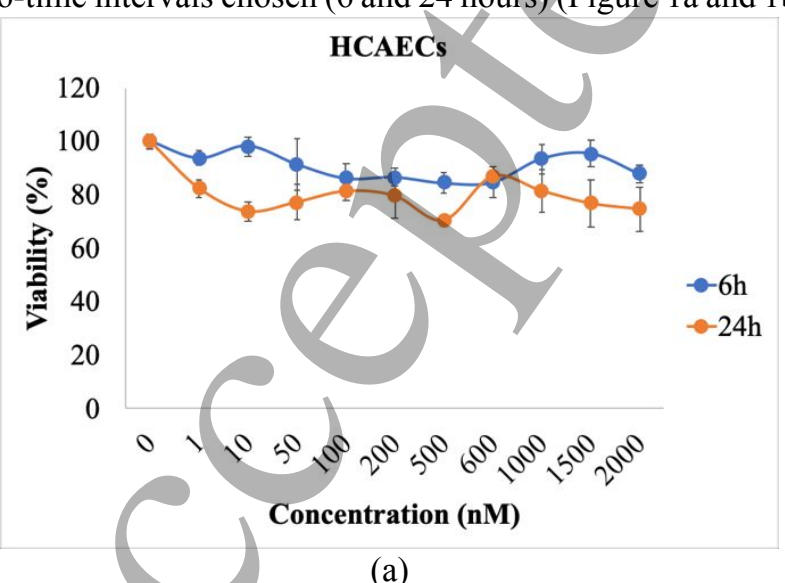

(a)

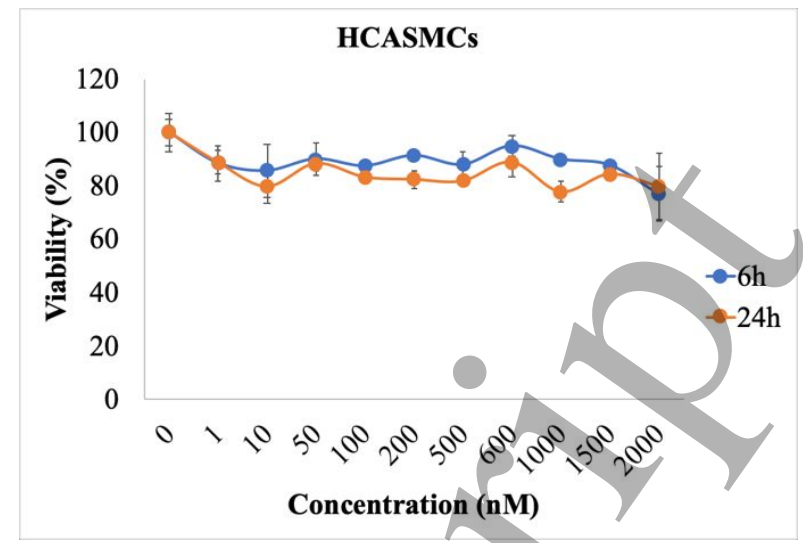

(b)

Figure 1. Cell viability was evaluated in HCAECs (a) and HCASMCs (b) static cultures exposed to incremental concentrations of Everolimus (1-2000 nM) for 6 and 24 hours.

Viability decreased below $80 \%$ after 24 hours and at high concentration levels (data not shown), these findings agreed with those of Fejes at al. [27]. Everolimus concentration chosen for cell experiments was $600 \mathrm{nM}$.

\subsection{Transcriptomic analysis}

Transcriptomic expression profiling showed that the samples are clustered according to their biological origin, confirming that shear stress between the groups, both in HCASMCs and HCAECs, is the major contributor to the variation in the data set (Figure 2).

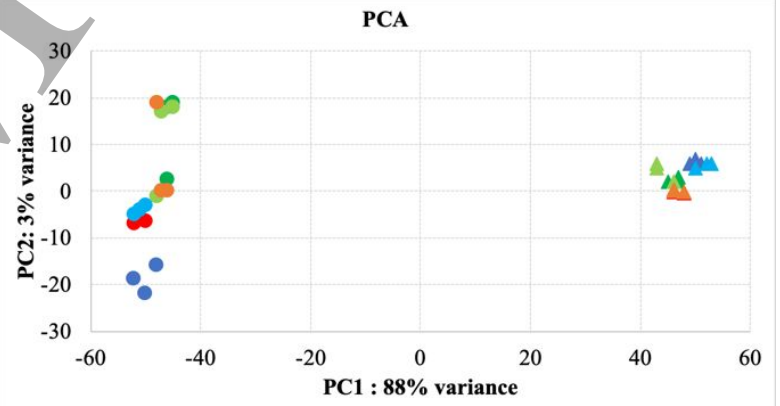

Figure 2. Principal component analysis (PCA) of HCASMCs (•) and HCAECs ( $\mathbf{\Delta})$ samples, based on expression levels, was showed in static without $(\bullet, \mathbf{\Delta})$ and with BVS + Drug $(\cdot, \mathbf{\Delta}), 1$ dyne without $(\bullet, \mathbf{\Delta})$ and with BVS+Drug (๑, $\mathbf{A}), 20$ dynes without $(\bullet, \mathbf{\Delta})$ and with BVS+Drug (०, $\triangle)$.

The principal component analysis indicated a low variability between the biological replicates. The global hierarchical clustering, focused on 100 most expressed genes, showed a separation of the samples, as illustrated in Figure 3. 


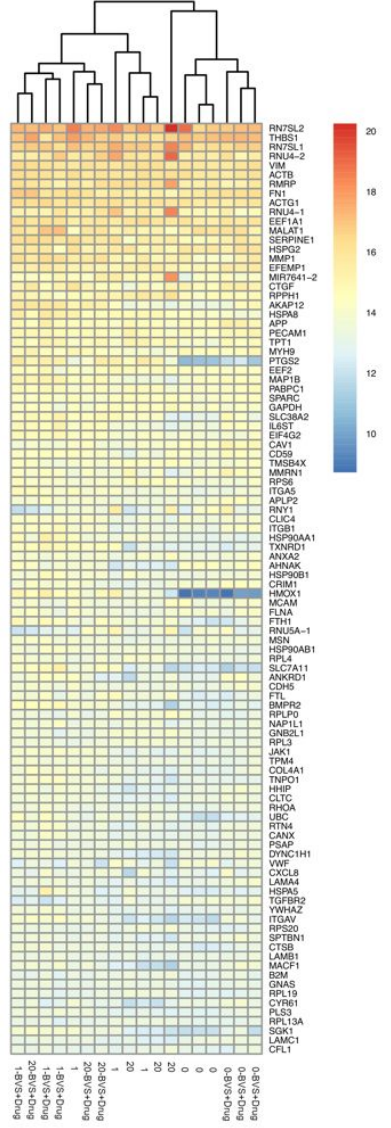

(a)

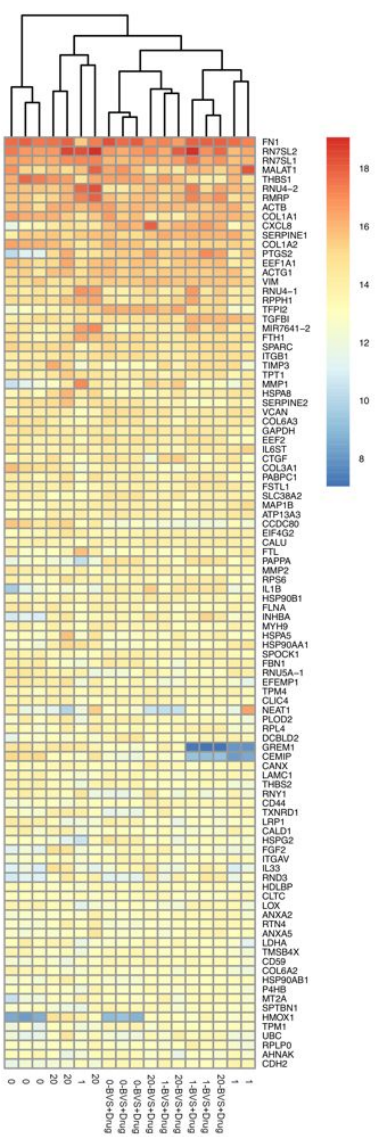

(b)

Figure 3. Cell clusterization of 100 most expressed genes in HCAECs (a) and HCASMCs (b) samples. Through the dendrogram of the mean expression values from replicated samples, a separation of all samples into distinct clusters was displayed.

Confirmed the separation between HCAECs and HCASMCs, for these last there was an evident difference between static and flow condition: in dynamic conditions was also evident the difference between cells treated with BVS+Drug and untreated ones.

\subsection{Overall findings of HCASMCS and HCAECS gene expression}

Transcriptome data was generated using messenger RNA (mRNA) sequencing of HCASMCs and HCAECs static and dynamic culture samples and were analyzed comparing the experimental conditions for HCASMCs and HCAECs, respectively. The stepwise workflow exploited to derive a small panel of relevant genes significantly associated with the main pathways of vessel pathobiology is the following:

Step 1. In-vitro cell model characterization. Gene expression changes associated to dynamic conditions as compared to the static state in HCASMCs and HCAECs (cases A, B, D, E) are assessed as also gene expression changes

associated to BVS+Drug application in static culture (case G) and dynamic conditions (cases $\mathrm{H}$ and $\mathrm{I}$ )

Step 2. In-vitro model of shear stress-related mRNA changes. Differential expression in a pathological SS-induced putative proatherogenic environment (case $\mathrm{C}$ ) and in a potentially pro-restenotic/thrombotic environment (case F) with its peculiar hemodynamic characteristics was classified trough GO approach and analyzed by direct comparison of genes present in the two conditions.

Step 3. Shared biological processes in HCASMCs and HCAECs with common relevant genes among the different cases (A-I) were analyzed through GO providing a condensed number of genes mostly involved in the pathological processes.

\subsection{Global modulation of gene expression}

Out of a total of 18,189 genes for which expression values have been evaluated using a general linear model, 2,086 $(11,5 \%)$ genes were found differentially expressed. By applying minimum FC criteria, for 537 genes $(2,95 \%$, Table 2) to be globally modulated, of which, $179(0,98 \%)$ down- and $358(2,96 \%)$ up-regulated in HCASMCs were found, while, for HCAECs modulated genes were $410(2,25 \%$, Table 3$)$ genes, $131(0,72 \%)$ down- and $279(1,53 \%)$ up-regulated (see Supplementary file).

\begin{tabular}{|c|c|c|c|c|c|}
\hline Cas & $\begin{array}{c}\text { HCASM } \\
\text { Cs } \\
\text { Different } \\
\text { ial } \\
\text { analysis }\end{array}$ & $\begin{array}{c}\text { Compari } \\
\text { son }\end{array}$ & $\begin{array}{c}\text { Numb } \\
\text { er of } \\
\text { genes }\end{array}$ & $\begin{array}{c}\text { DOW } \\
\mathbf{N}\end{array}$ & UP \\
\hline $\mathbf{A}$ & $\begin{array}{c}0 \text { vs } 1 \\
(\text { Group } 1 \\
\text { vs 2) }\end{array}$ & $\begin{array}{l}\text { Static vs } \\
\text { Dynamic } \\
\text { (Patho } \\
\text { SS) }\end{array}$ & 145 & $\begin{array}{c}71 \\
(48.9 \\
\%)\end{array}$ & $\begin{array}{c}74 \\
(51.1 \% \\
)\end{array}$ \\
\hline B & $\begin{array}{c}0 \text { vs } 20 \\
(\text { Group } 1 \\
\text { vs } 3)\end{array}$ & $\begin{array}{c}\text { Static vs } \\
\text { Dynamic } \\
\text { (Physio } \\
\text { SS) }\end{array}$ & 101 & $\begin{array}{c}27 \\
(26.7 \\
\%)\end{array}$ & $\begin{array}{c}74 \\
(73.3 \% \\
)\end{array}$ \\
\hline C & $\begin{array}{c}1 \text { vs } 20 \\
\text { (Group } 2 \\
\text { vs 3) }\end{array}$ & $\begin{array}{l}\text { Patho vs } \\
\text { Physio SS }\end{array}$ & 81 & $\begin{array}{c}26 \\
(32.0 \\
\%)\end{array}$ & $\begin{array}{c}55 \\
(68.0 \% \\
)\end{array}$ \\
\hline D & $\begin{array}{c}0- \\
\text { BVS+Dr } \\
\text { ug vs 1- } \\
\text { BVS+Dr } \\
\text { ug } \\
\text { (Group } 4 \\
\text { vs 5) }\end{array}$ & $\begin{array}{l}\text { Static vs } \\
\text { Dynamic } \\
\text { (Patho } \\
\text { SS) under } \\
\text { BVS+Dru } \\
\text { g }\end{array}$ & 56 & $\begin{array}{c}11 \\
(19.6 \\
\%)\end{array}$ & $\begin{array}{c}45 \\
(80.4 \% \\
)\end{array}$ \\
\hline $\mathbf{E}$ & $\begin{array}{c}0- \\
\text { BVS+Dr } \\
\text { ug vs 20- } \\
\text { BVS+Dr } \\
\text { ug }\end{array}$ & $\begin{array}{l}\text { Static vs } \\
\text { Dynamic } \\
\text { (Physio } \\
\text { SS) under }\end{array}$ & 64 & $\begin{array}{c}3 \\
(4.7 \% \\
)\end{array}$ & $\begin{array}{c}61 \\
(95.3 \% \\
)\end{array}$ \\
\hline
\end{tabular}




\begin{tabular}{|c|c|c|c|c|c|}
\hline & $\begin{array}{c}\text { (Group } 4 \\
\text { vs } 6)\end{array}$ & $\begin{array}{c}\text { BVS+Dru } \\
\mathrm{g}\end{array}$ & & & \\
\hline $\mathbf{F}$ & $\begin{array}{c}1- \\
\text { BVS+Dr } \\
\text { ug vs 20- } \\
\text { BVS+Dr } \\
\text { ug } \\
\text { (Group } 5 \\
\text { vs 6) }\end{array}$ & $\begin{array}{c}\text { Patho vs } \\
\text { Physio SS } \\
\text { under } \\
\text { BVS+Dru } \\
\text { g }\end{array}$ & 4 & $\begin{array}{c}0 \\
(0.0 \% \\
)\end{array}$ & $\begin{array}{c}4 \\
(100.0 \\
\%)\end{array}$ \\
\hline $\mathbf{G}$ & $\begin{array}{c}0 \text { vs } 0- \\
\text { BVS+Dr } \\
\text { ug } \\
\text { (Group } 1 \\
\text { vs 4) }\end{array}$ & $\begin{array}{c}\text { BVS+Dru } \\
\text { g effect in } \\
\text { Static }\end{array}$ & 23 & $\begin{array}{c}17 \\
(73.9 \\
\%)\end{array}$ & $\begin{array}{c}6 \\
(26.1 \% \\
)\end{array}$ \\
\hline H & $\begin{array}{c}1 \text { vs } 1- \\
\text { BVS+Dr } \\
\text { ug } \\
\text { (Group } 2 \\
\text { vs 5) }\end{array}$ & $\begin{array}{c}\text { BVS+Dru } \\
\text { g effect in } \\
\text { Dynamic } \\
\text { (Patho } \\
\text { SS) }\end{array}$ & 21 & $\begin{array}{c}6 \\
(28.6 \\
\%)\end{array}$ & $\begin{array}{c}15 \\
(71.4 \% \\
)\end{array}$ \\
\hline I & $\begin{array}{c}20 \text { vs 20- } \\
\text { BVS+Dr } \\
\text { ug } \\
\text { (Group } 3 \\
\text { vs 6) }\end{array}$ & $\begin{array}{l}\text { BVS+Dru } \\
\text { g effect in } \\
\text { Dynamic } \\
\text { (Physio } \\
\text { SS) }\end{array}$ & 42 & $\begin{array}{c}18 \\
(42.9 \\
\%)\end{array}$ & $\begin{array}{c}24 \\
(57.1 \% \\
)\end{array}$ \\
\hline
\end{tabular}

Table 2. Number of differentially expressed HCASMCs genes. The table shows the number of HCASMC genes modulated by the comparison of the different cell culture conditions described in Table 1. Selection criteria: $\mathrm{p}<0.01, \mathrm{FC} \pm 3$.

\begin{tabular}{|c|c|c|c|c|c|}
\hline $\begin{array}{l}\text { Ca } \\
\text { se }\end{array}$ & $\begin{array}{c}\text { HCAEC } \\
\text { s } \\
\text { Differen } \\
\text { tial } \\
\text { analysis }\end{array}$ & $\begin{array}{c}\text { Compari } \\
\text { son }\end{array}$ & $\begin{array}{c}\text { Numb } \\
\text { er of } \\
\text { genes }\end{array}$ & $\begin{array}{c}\text { DOW } \\
\mathbf{N}\end{array}$ & \\
\hline $\mathbf{A}$ & $\begin{array}{c}0 \text { vs } 1 \\
(\text { Group } 1 \\
\text { vs } 2)\end{array}$ & $\begin{array}{l}\text { Static vs } \\
\text { Dynamic } \\
\text { (Patho } \\
\text { SS) }\end{array}$ & 76 & & $\begin{array}{c}71 \\
(93.4 \\
\%)\end{array}$ \\
\hline B & $\begin{array}{c}0 \text { vs } 20 \\
(\text { Group } 1 \\
\text { vs } 3)\end{array}$ & $\begin{array}{c}\text { Static vs } \\
\text { Dynamic } \\
\text { (Physio } \\
\text { SS) }\end{array}$ & & & $\begin{array}{c}97 \\
(94.2 \\
\%)\end{array}$ \\
\hline C & $\begin{array}{c}1 \text { vs } 20 \\
\text { (Group } 2 \\
\text { vs 3) }\end{array}$ & $\begin{array}{l}\text { Patho vs } \\
\text { Physio SS }\end{array}$ & & $\begin{array}{c}1 \\
(0.9 \% \\
)\end{array}$ & $\begin{array}{c}10 \\
(99.1 \\
\%)\end{array}$ \\
\hline D & $\begin{array}{c}0- \\
\text { BVS+Dr } \\
\text { ug vs 1- } \\
\text { BVS+Dr } \\
\text { ug } \\
\text { (Group } 4 \\
\text { vs 5) }\end{array}$ & $\begin{array}{c}\text { Static vs } \\
\text { Dynamic } \\
\text { (Patho } \\
\text { SS) under } \\
\text { BVS+Dru } \\
\mathrm{g}\end{array}$ & 103 & $\begin{array}{c}41 \\
(39.8 \\
\%)\end{array}$ & $\begin{array}{c}62 \\
(60.2 \\
\%)\end{array}$ \\
\hline
\end{tabular}

\begin{tabular}{|c|c|c|c|c|c|}
\hline $\mathbf{E}$ & $\begin{array}{c}0- \\
\text { BVS+Dr } \\
\text { ug vs 20- } \\
\text { BVS+Dr } \\
\text { ug } \\
\text { (Group } 4 \\
\text { vs 6) }\end{array}$ & $\begin{array}{c}\text { Static vs } \\
\text { Dynamic } \\
\text { (Physio } \\
\text { SS) under } \\
\text { BVS+Dru } \\
\text { g }\end{array}$ & 35 & $\begin{array}{c}15 \\
(42.8 \\
\%)\end{array}$ & $\begin{array}{c}20 \\
(57.2 \\
\%)\end{array}$ \\
\hline $\mathbf{F}$ & $\begin{array}{c}1- \\
\text { BVS+Dr } \\
\text { ug vs 20- } \\
\text { BVS+Dr } \\
\text { ug } \\
\text { (Group } 5 \\
\text { vs 6) }\end{array}$ & $\begin{array}{c}\text { Patho vs } \\
\text { Physio SS } \\
\text { under } \\
\text { BVS+Dru } \\
\text { g }\end{array}$ & & $\begin{array}{c}(53.8 \\
\%)\end{array}$ & $\begin{array}{c}6 \\
(46.2 \\
\%)\end{array}$ \\
\hline $\mathbf{G}$ & $\begin{array}{c}0 \text { vs 0- } \\
\text { BVS+Dr } \\
\text { ug } \\
\text { (Group } 1 \\
\text { vs 4) }\end{array}$ & $\begin{array}{c}\text { BVS }+ \text { Dru } \\
\mathrm{g} \text { effect in } \\
\text { Static }\end{array}$ & 12 & $\begin{array}{c}3 \\
(25.0 \\
\%)\end{array}$ & $\begin{array}{c}9 \\
(75.0 \\
\%)\end{array}$ \\
\hline $\mathbf{H}$ & $\begin{array}{c}1 \text { vs 1- } \\
\text { BVS+Dr } \\
\text { ug } \\
\text { (Group } 2 \\
\text { vs 5) }\end{array}$ & $\begin{array}{l}\text { BVS+Dru } \\
\text { g effect in } \\
\text { Dynamic } \\
\text { (Patho } \\
\text { SS) }\end{array}$ & 12 & $\begin{array}{c}9 \\
(75.0 \\
\%)\end{array}$ & $\begin{array}{c}3 \\
(25.0 \\
\%)\end{array}$ \\
\hline I & $\begin{array}{c}20 \text { vs } 20- \\
\text { BVS+Dr } \\
\text { ug } \\
(\text { Group } 3 \\
\text { vs } 6)\end{array}$ & $\begin{array}{c}\text { BVS+Dru } \\
\text { g effect in } \\
\text { Dynamic } \\
\text { (Physio } \\
\text { SS) }\end{array}$ & 45 & $\begin{array}{c}44 \\
(97.8 \\
\%)\end{array}$ & $\begin{array}{c}1 \\
(2.2 \% \\
)\end{array}$ \\
\hline
\end{tabular}

Table 3. Number of differentially expressed HCAECs genes. The table shows the number of HCAEC genes modulated by the comparison of the different cell culture conditions described in Table 1. Selection criteria: $p<0.01, F C \pm 3$.

When subjected to flow conditions corresponding to 1 and 20 dyne $/ \mathrm{cm}^{2}$ SS values (case A, B), HCASMCs showed a larger increase of modulated genes as compared to HCAECs (246 vs. 179), with a prevalence of upregulated ones (148 vs. 11). On the other hand, the presence of BVS+Drug (case D, E), generated a pronounced reduction in genes modulation in HCASMCs (246 vs. 120) and HCAECs (179 vs. 138): in HCASMCs, BVS+Drug exerted a general trend of gene upregulation $(87,8 \%$ vs. $62,0 \%)$, while in HCAECs this tendency was attenuated (58,7\% vs. 93,8\%).

Pathological as compared to physiological SS (case C) had a deeper impact on smooth muscle cells, in which 81 genes are modulated compared to endothelial cells (11 genes): for both, the upregulation is prevalent, in particular in endothelial cells that show 99,1\% upregulated genes. When BVS+Drug is applied (case F), a different behavior in the two cell types is observed: in HCASMCs, BVS+Drug reduces the number of modulated genes (4 vs. 81), all upregulated while in endothelial cells the scaffold favors a small increase of 
modulated genes (13 vs. 11) with a more balanced ratio between up and down-regulation.

The application of BVS+Drug in static condition (case G) and at the same SS values in cases $H$ and I, leads to the following: the number of modulated genes is limited and stable in static setting and at $1 \mathrm{dyne} / \mathrm{cm}^{2}$, while strongly increases at 20 dyne $/ \mathrm{cm}^{2}$ (case I): twofold in HCASMCs, with balanced ratio between up and down-regulated genes (57,1\% vs. $42,9 \%$ ), and threefold in HCAECs with a prominent downregulation $(97,8 \%$ vs. $2,2 \%)$.

\subsection{Selected genes for restenosis and thrombosis model}

In HCASMCs, 81 genes (26 down-, 55 up-regulated) are modulated in case $C$ (Pathological vs. Physiologic SS in the absence of drug-eluting BVS) and only 4, all up-regulated, in case F (Pathological vs. Physiologic SS in the presence of drug-eluting BVS) as shown in Figure 4.

\section{HCASMCs}

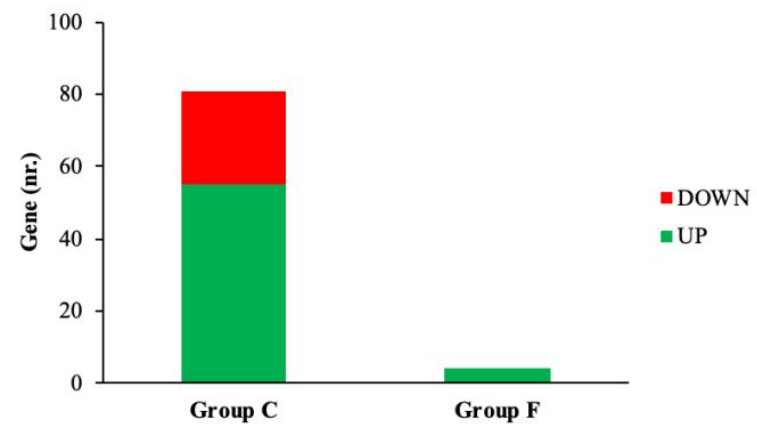

Figure 4. Number of up- and down-regulated HCASMCs genes in case $C$ and $F$.

The gene ontology analysis between cases $\mathrm{C}$ and $\mathrm{F}$ for HCASMCs shows a single common biological process, the angiogenesis pathway (Table 4) that includes SEMA3E (Semaphorin 3E). Specific biological processes, for case C (Table 4) were Positive regulation of coagulation [Thrombomodulin (THBD)] an Positive regulation of cell cycle [Insulin-like Growth Factor-1 (IGF1), Epiregulin (EREG) and Ubiquitin carboxyl-terminal hydrolase 2 (USP2)], while, for case F (Table 4), biological processes were Leukocyte migration [Selectin E (SELE)] and Fatty acid metabolic process [Elongation of very-long-chain fatty acids protein 7 (ELOVL7)].

\begin{tabular}{|c|c|c|c|c|}
\hline $\begin{array}{c}\text { GO } \\
\text { biological } \\
\text { process }\end{array}$ & $\begin{array}{c}\text { Gene } \\
\text { Symbol }\end{array}$ & Gene name & $\begin{array}{c}\text { Case } \\
\text { C } \\
\text { (FC) }\end{array}$ & $\begin{array}{c}\text { Case } \\
\text { F } \\
\text { (FC) }\end{array}$ \\
\hline $\begin{array}{c}\text { Angiogenesi } \\
\text { s }\end{array}$ & $\begin{array}{c}\text { SEMA3 } \\
\text { E }\end{array}$ & $\begin{array}{c}\text { Semaphorin } \\
\text { 3E }\end{array}$ & 3.21 & 3.82 \\
\hline $\begin{array}{c}\text { Positive } \\
\text { regulation } \\
\text { of } \\
\text { coagulation }\end{array}$ & THBD & $\begin{array}{c}\text { Thrombomod } \\
\text { ulin }\end{array}$ & 4.73 & - \\
\hline
\end{tabular}

\begin{tabular}{|c|c|c|c|c|}
\hline \multirow{2}{*}{$\begin{array}{c}\text { Positive } \\
\text { regulation } \\
\text { of cell cycle }\end{array}$} & IGF1 & $\begin{array}{c}\text { Insulin Like } \\
\text { Growth } \\
\text { Factor 1 }\end{array}$ & 3.07 & - \\
\cline { 2 - 5 } & EREG & Epiregulin & 6.11 & - \\
\cline { 2 - 5 } & USP2 & $\begin{array}{c}\text { Ubiquitin } \\
\text { Specific } \\
\text { Peptidase 2 }\end{array}$ & 3.62 & - \\
\hline $\begin{array}{c}\text { Leukocyte } \\
\text { migration }\end{array}$ & SELE & Selectin E & - & 8.43 \\
\hline $\begin{array}{c}\text { Fatty acid } \\
\text { metabolic } \\
\text { process }\end{array}$ & $\begin{array}{c}\text { ELOVL } \\
7\end{array}$ & $\begin{array}{c}\text { ELOVL Fatty } \\
\text { Acid } \\
\text { Elongase 7 }\end{array}$ & & 3.20 \\
\hline
\end{tabular}

Table 4. Gene Ontology biological processes in HCASMCs. Biological processes in HCASMCs exposed to pathological and physiological SS values, without (Case C) and with (Case F) application of $B V S+$ Drug.

In HCAECs, 11 genes (1 down-, 10 up-regulated) are modulated in case $C$ and 13 (7 down-, 6 up-regulated) in case F (Figure 5).

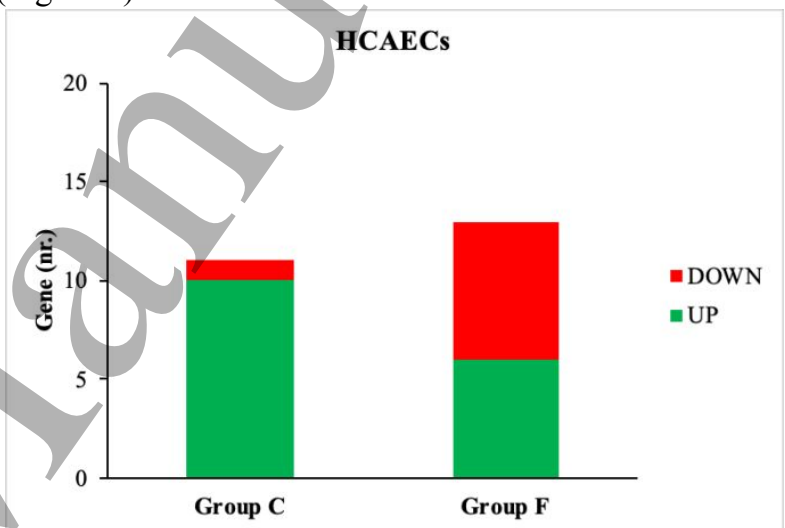

Figure 5. Number of up- and down-regulated HCAECs genes in case $C$ and $F$.

The gene ontology analysis between case $\mathrm{C}$ and $\mathrm{F}$ for HCAECs showed a single common biological process, the blood circulation pathway [Mesenchyme homeobox 2 (MEOX2), Table 5]; specific biological processes correlated with the specific aim of the work were, for case C (Table 5), Leukocyte migration (SELE), Inflammatory response (SELE) and Regulation of mitotic cell cycle (USP2), while, for case F (Table 5), underlined biological processes were Response to fibroblast growth factor [Fibroblast Growth Factor 1 (FGF1), Cytoplasmatic vesicle membrane (Frizzled Class Receptor 2 (FZD2)], Response to lipid [Wnt Family Member 5B (WNT5B] and Response to insulin (FGF1).

\begin{tabular}{|c|c|c|c|c|}
\hline $\begin{array}{c}\text { GO biological } \\
\text { process }\end{array}$ & $\begin{array}{c}\text { Gene } \\
\text { Symbol }\end{array}$ & Gene name & $\begin{array}{c}\text { Case } \\
\text { C } \\
\text { (FC) }\end{array}$ & $\begin{array}{c}\text { Case } \\
\text { F } \\
\text { (FC) }\end{array}$ \\
\hline $\begin{array}{c}\text { Blood } \\
\text { circulation }\end{array}$ & MEOX2 & $\begin{array}{c}\text { Mesenchyme } \\
\text { Homeobox 2 }\end{array}$ & 3.30 & 4.03 \\
\hline $\begin{array}{c}\text { Leukocyte } \\
\text { migration }\end{array}$ & SELE & Selectin E & -3.11 & - \\
\hline
\end{tabular}




\begin{tabular}{|c|c|c|c|c|}
\hline $\begin{array}{c}\text { Inflammatory } \\
\text { response }\end{array}$ & SELE & Selectin E & -3.11 & - \\
\hline $\begin{array}{c}\text { Regulation of } \\
\text { mitotic cell } \\
\text { cycle }\end{array}$ & USP2 & $\begin{array}{c}\text { Ubiquitin } \\
\text { Specific } \\
\text { Peptidase 2 }\end{array}$ & 4.07 & - \\
\hline $\begin{array}{c}\text { Response to } \\
\text { fibroblast } \\
\text { growth factor }\end{array}$ & FGF1 & $\begin{array}{c}\text { Fibroblast } \\
\text { Growth } \\
\text { Factor 1 }\end{array}$ & - & -3.77 \\
\hline $\begin{array}{c}\text { Cytoplasmatic } \\
\text { vesicle } \\
\text { membrane }\end{array}$ & FZD2 & $\begin{array}{c}\text { Frizzled } \\
\text { Class } \\
\text { Receptor 2 }\end{array}$ & - & 3.09 \\
\hline $\begin{array}{c}\text { Response to } \\
\text { lipid }\end{array}$ & WNT5B & $\begin{array}{c}\text { Wnt Family } \\
\text { Member 5B }\end{array}$ & - & -3.89 \\
\hline $\begin{array}{c}\text { Response to } \\
\text { insulin }\end{array}$ & FGF1 & $\begin{array}{c}\text { Fibroblast } \\
\text { Growth } \\
\text { Factor 1 }\end{array}$ & - & -3.77 \\
\hline
\end{tabular}

Table 5. Gene Ontology biological processes in HCAECs. Biological processes in HCAECs exposed to pathological and physiological SS values, without (Case C) and with (Case F) application of BVS+Drug.

This experimental set-up aims at in-vitro modeling of both the atherosclerotic plaque formation (C) as well as of restenosis/thrombosis after drug-eluting BVS implantation (F). The presence of a common gene between these two experimental conditions suggests a general relevance of SEMA3E (Table 4) and MEOX2 (Table 5) in pathological SSinduced vessel wall pathology.

\subsection{Shared biological processes and common genes}

The analysis was focused on the selection of genes sharing the same biological processes both between the two cell types as well as in the pathways specific to each cell type. The list of genes selected in HCASMCs (270 genes) and HCAECs (202), expressed in the conditions A-I of Tables 3 and 4, generated a map of interactions, comprehensive of several biological processes.

Comparing the results, only three genes were constantly present: Bone Morphogenetic Protein 4 (BMP4), Heme Oxygenase 1 (HMOX1), and SELE. These genes were present in 4 biological processes shared by HCASMCs and HCAECs, 2 specific processes of HCASMCs, and 2 specific processes of HCAECs, as reported in Table 6.

\begin{tabular}{|c|c|c|c|c|c|}
\hline $\begin{array}{c}\text { NR } \\
\text {. }\end{array}$ & $\begin{array}{c}\text { GO } \\
\text { biological } \\
\text { process }\end{array}$ & $\begin{array}{c}\text { HMO } \\
\text { X1 }\end{array}$ & $\begin{array}{c}\text { BMP } \\
4\end{array}$ & $\begin{array}{c}\text { SEL } \\
\text { E }\end{array}$ & Samples \\
\hline 1 & $\begin{array}{c}\text { Epithelial } \\
\text { cell } \\
\text { proliferatio } \\
n\end{array}$ & & $\sqrt{ }$ & & $\begin{array}{c}\text { HCASM } \\
\text { Cs }+ \\
\text { HCAECs }\end{array}$ \\
\hline 2 & $\begin{array}{c}\text { Sprouting } \\
\text { angiogenesi } \\
\mathrm{s}\end{array}$ & & $\sqrt{ }$ & & $\begin{array}{c}\text { HCASM } \\
\text { Cs }+ \\
\text { HCAECs }\end{array}$ \\
\hline
\end{tabular}

\begin{tabular}{|c|c|c|c|c|}
\hline 3 & $\begin{array}{c}\text { Blood } \\
\text { vessel } \\
\text { developmen } \\
t\end{array}$ & $\sqrt{ }$ & $\sqrt{ }$ & $\begin{array}{c}\text { HCASM } \\
\text { Cs }+ \\
\text { HCAECs }\end{array}$ \\
\hline 4 & $\begin{array}{c}\text { Regulation } \\
\text { of } \\
\text { phospholip } \\
\text { ase C } \\
\text { activity }\end{array}$ & & & $\mathrm{ECs}$ \\
\hline 5 & $\begin{array}{l}\text { Leukocyte } \\
\text { migration }\end{array}$ & & & $\begin{array}{c}\text { HCASM } \\
\text { Cs }\end{array}$ \\
\hline 6 & $\begin{array}{c}\text { Smooth } \\
\text { muscle cell } \\
\text { proliferatio } \\
n\end{array}$ & & & $\begin{array}{c}\text { HCASM } \\
\text { Cs }\end{array}$ \\
\hline 7 & $\begin{array}{c}\text { Angiogenes } \\
\text { is }\end{array}$ & & & HCAECs \\
\hline 8 & $\begin{array}{l}\text { Inflammato } \\
\text { ry response }\end{array}$ & & & HCAECs \\
\hline
\end{tabular}

Table 6. Shared genes in HCASMCs and HCAECs associated to Gene Ontology biological processes Main biological processes related to relevant genes previously selected from differential analysis: GO biological process shared by both HCAECs and HCASMCs (1-4) HCASMCs-specific $(5,6)$ and HCAECs-specific $(7,8)$.

\subsection{Network analysis}

miRNET system was used to enhance and better understand regulatory relations that take place among the identified genes. To limit the large amount of regulators predicted targets, only confirmed by miRTarBase v8.0, TarBase v8.0 and miRecords (for miRNAs) and TransmiR v2.0 (for TFs) databases were collected [30].

The enhanced network is depicted in Figure 6 and the list of enhanced entities (TFs and miRNAs) is reported in Table 7. 


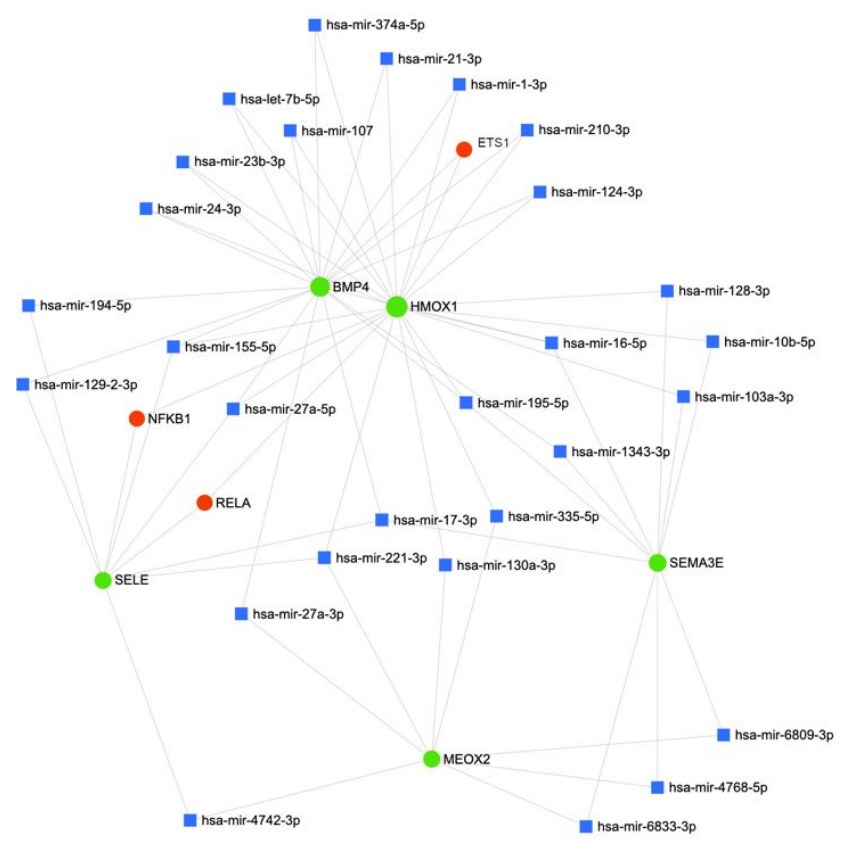

Figure 6. Schematic representation of the enhanced network. Green circles represent the five selected genes, blue squares represent microRNAs, and red circles represent transcription factors.

The proposed enhanced network shows the interaction of the five genes, further enlarging the set of regulations and highlighting the presence of common regulatory motif composed by TFs and microRNAs, that possibly finely tune the pathway behavior.

\begin{tabular}{|c|c|c|}
\hline Node & Type & Overall function \\
\hline hsa-mir-16 & miRNA & $\begin{array}{l}\text { Cell proliferation } \\
\text { and angiogenesis }\end{array}$ \\
\hline hsa-mir-17 & miRNA & Apoptosis \\
\hline hsa-mir-221 & miRNA & $\begin{array}{l}\text { Cell migration, } \\
\text { differentiation and } \\
\text { proliferation }\end{array}$ \\
\hline hsa-mir-155 & miRNA & Inflammation \\
\hline hsa-mir-27a & miRNA & Cell proliferation \\
\hline hsa-mir-195 & miRNA & $\begin{array}{l}\text { Inflammation and } \\
\text { growth factors } \\
\text { regulation }\end{array}$ \\
\hline hsa-mir-374a & miRNA & Cell adhesion \\
\hline hsa-mir-21 & miRNA & Angiogenesis \\
\hline hsa-mir-1 & miRNA & Angiogenesis \\
\hline hsa-mir-210 & & $\begin{array}{l}\text { VSMC apoptosis, } \\
\text { EC migration, } \\
\text { Angiogenesis }\end{array}$ \\
\hline hsa-mir-124 & miRNA & $\begin{array}{l}\text { Inflammation, } \\
\text { VSMC } \\
\text { proliferation }\end{array}$ \\
\hline hsa-let-7b & miRNA & $\begin{array}{c}\text { Apoptosis, } \\
\text { Angiogenesis, EC } \\
\text { proliferation }\end{array}$ \\
\hline hsa-mir-107 & miRNA & VEGF production \\
\hline
\end{tabular}

\begin{tabular}{|c|c|c|}
\hline hsa-mir-23b & miRNA & Angiogenesis \\
\hline hsa-mir-24 & miRNA & $\begin{array}{l}\text { EC proliferation, } \\
\text { VSMC apoptosis }\end{array}$ \\
\hline hsa-mir-194 & miRNA & Inflammation \\
\hline hsa-mir-129-2 & miRNA & $\begin{array}{c}\text { Inflammation, EC } \\
\text { proliferation }\end{array}$ \\
\hline hsa-mir-128 & miRNA & $\begin{array}{l}\text { Cholesterol efflux } \\
\text { and homeostasis }\end{array}$ \\
\hline hsa-mir-10b & miRNA & $\begin{array}{c}\text { EC proliferation, } \\
\text { Angiogenesis }\end{array}$ \\
\hline hsa-mir-103a & miRNA & $\begin{array}{l}\text { Glucose } \\
\text { homeostasis }\end{array}$ \\
\hline hsa-mir-1343 & miRNA & n.a. \\
\hline hsa-mir-335 & miRNA & n.a. \\
\hline hsa-mir-130a & miRNA & $\begin{array}{l}\text { Proliferation, } \\
\text { Angiogenesis }\end{array}$ \\
\hline hsa-mir-6809 & miRNA & n.a. \\
\hline hsa-mir-4768 & miRNA & n.a. \\
\hline hsa-mir-6833 & miRNA & n.a. \\
\hline hsa-mir-27a & miRNA & Proliferation \\
\hline hsa-mir-4742 & miRNA & n.a. \\
\hline & $\begin{array}{c}\text { Transcriptional } \\
\text { factor }\end{array}$ & $\begin{array}{c}\text { Angiogenesis, EC } \\
\text { migration, } \\
\text { Inflammation }\end{array}$ \\
\hline & $\begin{array}{l}\text { Transcriptional } \\
\text { factor }\end{array}$ & $\begin{array}{c}\text { Inflammation, } \\
\text { Cholesterol } \\
\text { transport }\end{array}$ \\
\hline RELA & $\begin{array}{l}\text { Transcriptional } \\
\text { factor }\end{array}$ & NFKB regulation \\
\hline
\end{tabular}

Table 7, List of microRNA and transcription factors obtained in enhancing process.

\section{Discussion}

In the present study, human coronary vascular cells (HCASMCs and HCAECs) were used, to study the effect of drug-eluting BVS on gene expression and identify differentially expressed genes as potentially related to the molecular pathway of restenosis and thrombosis, after application of BVS to vascular cells. HCASMCs and HCAECs were cultured in static and dynamic (shear stress of 1 and 20 dyne $/ \mathrm{cm}^{2}$ ) conditions, with and without BVS and drug: 1 and $20 \mathrm{dyne} / \mathrm{cm}^{2}$ are representative, the first, of a pathological disturbed flow and, the second, of physiological flow conditions [31,32]. Vascular cell RNA was isolated and the transcriptomic profile was analyzed. Comparing different cell culture conditions and with the support of Gene Ontology (GO) analysis, a group of genes related to neointima formation, angiogenesis, thrombosis, and inflammation were highlighted.

Genes selected by transcriptomic analysis (BMP4, HMOX1, SELE, SEMA3E, MEOX2) have been previously analyzed for their role, at different levels, in vascular disease development but no integrated approach as described in this 
article, has been ever reported, nor applied to evaluate BVS interaction with vascular cells so far.

From a toxicological point of view, cell viability is preserved above $80 \%$ after 6 hours and decreasing below $80 \%$ after 24 hours at high concentration levels (Figure 2), confirming results of literature [27].

Focusing on the PCA and hierarchical distribution of samples in transcriptomic analysis, the presence of BVS+Drug seems to operate a strong phenotype modulation in particular when cells are cultured in dynamic conditions.

Starting from a general, comprehensive point of view, the higher number of modulated (mostly upregulated) genes in HCASMCs (537 genes) compared to HCAECs (410 genes) in all the experimental settings can be explained by the specific cell physiological roles. Indeed, endothelial cells are naturally exposed to the shear stress produced by blood flow, while smooth muscle cells are not directly exposed to shear forces thus they can be more sensible to this mechanical stimulation. This fact can explain the higher number of modulated (mostly upregulated) genes in HCASMCs compared to HCAECs. In addition, BVS+Drug application effects more the gene expression of both cell types when cultured in dynamic conditions.

A more specific analysis of the modulated pathways in the different experimental conditions allowed the underlining of a restricted number of genes and among these of interest SEMA3E, significantly upregulated in HCASMCs, and MEOX2, upregulated in HCAECs.

Semaphorins are a family of proteins originally discovered as axon guidance [33], among them, SEMA3E interacts with its receptor, plexinD1, regulating migration and inhibiting endothelial cell proliferation [34]. Inactivation of PlexinD1 in mice embryos leads to congenital heart diseases, absence or atresia of left carotid arteries and less VSMCs coverage of aortic arch arteries [35]. Wu et al. showed how the expression of SEMA3E in VSMCs is progressively decreased during neointimal hyperplasia and is down-regulated in human atherosclerotic arteries while the replenishment of SEMA3E caused a significant reduction of neointimal hyperplasia [21].

Homeobox genes are transcription factors that regulate normal development, phenotype cell identity and control primary cellular processes [36]. MEOX2 (Mesenchyme Homeobox 2) encodes a transcription factor expressed both in smooth muscle and endothelial cells and it has been suggested as master regulatory gene for the angiogenic phenotype [37]. MEOX2 expression, maximal in quiescent ECs but rapidly down-regulated in response to serum and proinflammatory factors, inhibits EC proliferation and angiogenesis [38].

Among the biological processes shared by HCASMCs and HCAECs, three genes are constantly upregulated in pathological shear stress, thus pathological conditions: BMP4, HMOX1 and SELE.

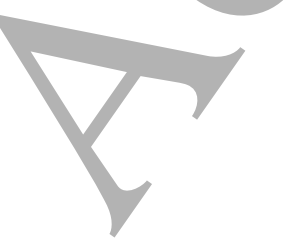

BMPs are members of the Transforming Growth Factor (TGF)- $\beta$ superfamily. BMP4 (Bone Morphogenetic Protein 4), together with BMP2, has been shown to play an essential role in cardiovascular physiology and pathophysiology [39] angiogenesis, neointima formation and development of pulmonary hypertension [23]. Studies suggest that BMPs are upregulated at atheroprone regions in blood vessels and may contribute to vascular calcification and the development of atherosclerotic plaques [40]. Because BMP4 elicits endothelial activation and dysfunction, hypertension, and vascular calcification, inhibition of BMP4 expression by shear stress is likely to exert antiatherogenic and vasculoprotective effects.

Heme oxygenase catalyzes the oxidative degradation of Heme into biliverdin, carbon monoxide, and free iron [41]. It is mainly represented by an inducible isoform, HMOX1 (Heme Oxygenase 1), that plays a cytoprotective role in modulating tissue responses to injury [42]. Activation of HMOX1 in endothelial cells is crucial for pro-angiogenic response to VEGF since/pharmacological inhibition of HMOX1 or knockout of HMOX1 gene impair proliferation, migration, and angiogenic potency of VEGF-stimulated endothelial cells [43]. However, the role of HMOX1 in angiogenesis depends on the underlying conditions since, for example, the inflammation-induced blood vessel formation is attenuated, whereas VEGF-driven non-inflammatory angiogenesis is facilitated by HMOX1 [44]. Expression of HMOX1 in atherosclerotic lesions, its ability to inhibit vascular smooth muscle cell proliferation and to exert antiinflammatory, antioxidant, and antithrombotic effects suggest a protective role during atherogenesis [45]. Furthermore, HMOX1 in endothelial cells exposed to oscillatory flow is markedly attenuated [46].

Hematopoietic cells, as well as endothelial cells, express three known types of selectins: SELP, SELE and SELL [47]. These adhesion molecules mediate rapid on-off interactions and it has been suggested that shear stress may activate some selectin-mediated events, which lead to "tethering" or shortlived adhesion between cells [48]. SELE is primarily expressed by activated endothelial cells following inflammatory stimuli. [49].

In order to evidence potential correlation among these genes we integrated network enhancing analysis to point up miRNAs and TFs involved in underlined pathway modulation.

Figure 6 summarizes the results obtained. The enhancing process added to the network 30 new interactors (3 transcription factors and 27 miRNAs) (Table 7), each of them has been assessed to evaluate its role. Interestingly, several of the regulators appear strongly related to the cell proliferation and angiogenesis. The transcription factors, appeared in the network, seem to link different pathways and factors: in particular, ETS1, RELA and NFKB1 (these last two often associate in a complex), have been described having pivotal 
roles in vascular inflammation and EC and VSMC activation [50-53] . The 28 miRNAs present different multiple functions, in particular: 9 are involved in proliferation, 7 in angiogenesis, 5 in inflammatory response, 4 in apoptosis, 6 in other function (glucose homeostasis, VEGF production, cholesterol efflux and homeostasis, cell migration, differentiation, cell adhesion) and finally, for the remaining 6 no specific function was currently defined. Interesting, among the miRNAs, three of them (miR-16, miR-155 and miR-195) are involved in the regulation of inflammatory pathways related to atherogenesis [54-56]. Moreover, miR-155 seems to be responsible of the destruction of tight junctions and endothelial barriers enhancing atherosclerotic progression and inhibiting reendothelialisation [55].

Finally, mir-221 is also implicated in maintaining endothelial integrity and in atherosclerotic vessels it activates VSMCs towards the "synthetic" pathological phenotype [57].

\section{Conclusion}

ISR and ST, caused by stent procedures, represent a major clinical problem. A better understanding of the underlying and causative mechanisms responsible for initiating and sustaining such detrimental effects on the coronary bed is needed to prevent these drawbacks.

The results of this study suggest that the phenotypic environment of cells under combination of BVS+Drug and hemodynamic disturbed flow conditions could lead to a hyperplasic and pro-atherogenic (SEMA3E, BMP4), proinflammatory (MEOX2), impaired vascularization (MEOX2, HMOX1) and pro-adherent condition (SELE). Furthermore, a moderate pro-adherent platelet phenotype and pro-thrombotic (HMOX1) environment associated with BVS+Drug and low ESS suggested the necessity for an intensive antiplatelet treatment following stent deployment in clinical practice.

The novelty of this study consists, as first work in literature of this type on BVS, in the evaluation molecular effects of vascular scaffolds on the separate main cellular components of arterial wall: our transcriptomic approach allowed the identification of potential gene and miRNA networks able to explain the mechanisms involved in the disease onset and development.

The combined evaluation of shear stress and Everolimuseluting BVS application to in-vitro cell cultures shed light on the biological mechanisms and the leading molecular actors involved in the development of restenosis and thrombosis associated to stent deployment.

\subsection{Study limitations}

The experimental nature of this work requires further clinical studies to quantify how the genes as well as their related proteins are expressed in the plasma of patients before exploiting these molecules as potential candidate biomarkers of IR and ST in revascularized patients treated by BVS.
Besides some methodological drawbacks, our approach was commonly used in similar in-vitro studies and the profile of the selected panel of genes should be tested in pathological tissue-derived vascular cells as further confirmation. Furthermore, the aim of this work was to evaluate BVS as the most promising approach thus different types of stents, mainly the commonly used DES, have not been tested. For this reason, information whether the same genes are modulated in different stents are currently not available.

A major outcome of this work is the deduction that the implemented in-vitro experimental model of HCAECs and HCASMCs is methodologically reliable and adequate to investigate the underlying cellular mechanisms of in vivo stent complications. Differential analysis of the experimental conditions tested allowed the identification of 537 genes significantly modulated in HCASMCs (179 down- and 358 up-regulated), and 410 in HCAECs (131 down- and 279 upregulated). Flow shear stress has a more significant impact on SMCs compared to ECs ( 81 vs. 11 modulated), as expected from their biological role. The three-step workflow of differential analysis of transcriptomic results highlights the relevance in pathological conditions of MEOX2 (EC proliferation, angiogenesis and inflammation), SEMA3E (VSMC migration and proliferation), BMP4 (angiogenesis), HMOX1 (inflammation, thrombosis) and SELE (leukocyte migration).

\section{Ackwnoledgement}

We would thank IGA Technology for their support in transcriptomic and data analysis.

\section{Disclosure}

The authors declare that they have no conflict of interest.

\section{Funding}

This study was supported by the European Union's Horizon 2020 research and innovation programme under grant agreement No 777119 (InSilc project). This article reflects only the author's view and the Commission is not responsible for any use that may be made of the information it contains.

\section{References}

[1] Herrington W, Lacey B, Sherliker P, Armitage J and Lewington S 2016 Epidemiology of Atherosclerosis and the Potential to Reduce the Global Burden of Atherothrombotic Disease. Circ Res 118 535-46

Fischman D L, Leon M B, Baim D S, Schatz R A, Savage M P, Penn I, Detre K, Veltri L, Ricci D and Nobuyoshi M 1994 A randomized comparison of coronary-stent placement and balloon angioplasty in the treatment of coronary artery disease. Stent Restenosis Study Investigators. N Engl J Med 331 496-501 
[3] Vozzi F, Mazzei D, Vinci B, Vozzi G, Sbrana T, Ricotti L, Forgione N and Ahluwalia A 2011 A flexible bioreactor system for constructing in vitro tissue and organ models Biotechnol. Bioeng. 108 2129-40

[4] Rzeszutko L, Depukat R and Dudek D 2013 Biodegradable vascular scaffold ABSORB BVSTM scientific evidence and methods of implantation. Postepy Kardiol Interwencyjnej 9 22-30

[5] Panoulas V F, Mastoris I, Devices K K M2015 Everolimus-eluting stent platforms in percutaneous coronary intervention: comparative effectiveness and outcomes ncbi.nlm.nih.gov

[6] Vitiello D, Neagoe P-E, Sirois M G and White M 2015 Effect of everolimus on the immunomodulation of the human neutrophil inflammatory response and activation. Cell Mol Immunol 12 40-52

[7] Hiltrop N, Jorge C, Bennett J and Adriaenssens T 2016 Late neoatherosclerotic scaffold failure: An unexpected achilles heel for current bioresorbable scaffold technology? Int J Cardiol 223 133-5

[8] Baquet M, Nef H, Gori T, Latib A, Capodanno D, Di Mario C, Sabaté M, Colombo A, Tamburino C and Mehilli J 2018 Restenosis patterns after bioresorbable vascular scaffold implantation: Angiographic substudy of the GHOST-EU registry. Catheter Cardiovasc Interv 92 276-82

[9] Ashley E A, Ferrara R, King J Y, Vailaya A, Kuchinsky A, He X, Byers B, Gerckens U, Oblin S, Tsalenko A, Soito A, Spin J M, Tabibiazar R, Connolly A J, Simpson J B, Grube E and Quertermous T 2006 Network analysis of human in-stent restenosis Circulation 114 2644-54

[10] Ge J, Song C, Zhang C, Liu X, Chen J, Dou K and Chen L 2020 Personalized Early-Warning Signals during Progression of Human Coronary Atherosclerosis by Landscape Dynamic Network Biomarker. Genes (Basel) 11676

[11] Kipshidze N, Dangas G, Tsapênko M, Moses J, Leon M B, Kutryk M and Serruys P 2004 Role of the endothelium in modulating neointimal formation: vasculoprotective approaches to attenuate restenosis after percutaneous coronary interventions. $J$ Am Coll Cardiol 44 733-9

[12] Cecchettini A, Rocchiccioli S, Boccârdi C and Citti L 2011 Vascular smooth-muscle-cell activation: proteomics point of view. Int Rev Cell Mol Biol $28843-$ 99

[13] Newby A C and Zaltsman A B 2000 Molecular mechanisms in intimal hyperplasia. The Journal of Pathology 190 300-9
[14] Marx S O, Totary-Jain H and Marks A R 2011 Vascular smooth muscle cell proliferation in restenosis. Circ Cardiovasc Interv 4 104-11

[15] Lekshmi K M, Che H-L, Cho C S and Park IK 2017 Drug- and Gene-eluting Stents for Preventing Coronary Restenosis. Chonnam Med J 53 14-27

[16] Braddock M, Schwachtgen J-L, Houston P, Dickson M C, Lee M J and Campbell C J 1998 Fluid Shear Stress Modulation of Gene Expression in Endothelial Cells. News Physiol. Sci. 13 241-6

Vozzi F, Campolo J, Cozzi L, Politano G, Di Carlo S, Rial M, Domenici C and Parodi O 2018 Computing of Low Shear Stress-Driven Endothelial Gene Network Involved in Early Stages of Atherosclerotic Process. BioMed Research International 2018 5359830-12

[18] Chatterjee S 2018 Endothelial Mechanotransduction, Redox Signaling and the Regulation of Vascular Inflammatory Pathways. Frontiers in Physiology 9524

[19] Lin J, Friesen M T, Bocangel P, Cheung D, Rawszer K and Wigle J T 2005 Characterization of Mesenchyme Homeobox 2 (MEOX2) transcription factor binding to RING finger protein 10. Mol Cell Biochem 275 75-84

[20] Zheng H, Hu Z, Zhai X, Wang Y, Liu J, Wang W and Xue S 2016 Gax regulates human vascular smooth muscle cell phenotypic modulation and vascular remodeling. Am J Transl Res 8 2912-25

Wu J-H, Li Y, Zhou Y-F, Haslam J, Elvis O N, Mao L, Xia Y-P and Hu B 2017 Semaphorin-3E attenuates neointimal formation via suppressing VSMCs migration and proliferation. Cardiovasc Res 113 1763-75

Kishimoto Y, Kondo K and Momiyama Y 2019 The Protective Role of Heme Oxygenase-1 in Atherosclerotic Diseases. IJMS 20

[23] Sorescu G P, Sykes M, Weiss D, Platt M O, Saha A, Hwang J, Boyd N, Boo Y C, Vega J D, Taylor W R and Jo $\mathrm{H} 2003$ Bone morphogenic protein 4 produced in endothelial cells by oscillatory shear stress stimulates an inflammatory response. J Biol Chem 278 31128-35

Chen L-J, Lee C-I, Lee P-L, Lee D-Y, Tsai M-C, Lin C$\mathrm{W}$ and Chien S 2007 Mechanisms of induction of endothelial cell E-selectin expression by smooth muscle cells and its inhibition by shear stress Blood 110 519-28

Leopold J A and Loscalzo J 2018 Emerging Role of Precision Medicine in Cardiovascular Disease. Circ Res 122 1302-15

Casamassimi A, Federico A, Rienzo M, Esposito S and Ciccodicola A 2017 Transcriptome Profiling in Human Diseases: New Advances and Perspectives. IJMS 18 1652 
Fejes Z, Czimmerer Z, Szük T, Póliska S, Horváth A, Balogh E, Jeney V, Váradi J, Fenyvesi F, Balla G, Édes I, Balla J, Kappelmayer J and Nagy B 2018 Endothelial cell activation is attenuated by everolimus via transcriptional and post-transcriptional regulatory mechanisms after drug-eluting coronary stenting. ed M F Romano PLOS ONE 13 e0197890

[28] Anders S and Huber W 2010 Differential expression analysis for sequence count data. Genome Biol. 11 R106-12

[29] Love M I, Huber W and Anders S 2014 Moderated estimation of fold change and dispersion for RNA-seq data with DESeq2. Genome Biol. 15 550-21

[30] Chang L, Zhou G, Soufan O and Xia J 2020 miRNet 2.0: network-based visual analytics for miRNA functional analysis and systems biology. Nucleic Acids Res. 48 W244-51

[31] Malek A M, Alper S L and Izumo S 1999 Hemodynamic shear stress and its role in atherosclerosis. JAMA 282 2035-42

[32] Thondapu V, Tenekecioglu E, Poon E K W, Collet C, Torii R, Bourantas C V, Chin C, Sotomi Y, Jonker H, Dijkstra J, Revalor E, Gijsen F, Onuma Y, Ooi A, Barlis P and Serruys P W 2018 Endothelial shear stress 5 years after implantation of a coronary bioresorbable scaffold European Heart Journal 39 1602-9

[33] Roth L, Koncina E, Satkauskas S, Crémel G, Aunis D and Bagnard D 2009 The many faces of semaphorins: from development to pathology. Cellular and Molecular Life Sciences (CMLS) 66 649-66

[34] Moriya J, Minamino T, Tateno K, Okada S, Uemura A Shimizu I, Yokoyama M, Nojima A, Okada M, Koga H and Komuro I 2010 Inhibition of semaphorin as a novel strategy for therapeutic angiogenesis. Circ Res $106391-$ 8

[35] Zhang Y, Singh M K, Degenhardt K R, Lu M M, Bennett J, Yoshida Y and Epstein J A 2009 Tie2Cremediated inactivation of plexinD1 results in congenital heart, vascular and skeletal defects. Dev. Biol. 325 82-93

[36] Cillo C, Cantile M, Faiella A and Boncinelli E 2001 Homeobox genes in normal and malignant cells. J. Cell. Physiol. 188 161-9

[37] Gorski D H and Leal A J 2003 Inhibition of endothelial cell activation by the homeobox gene Gax. J Surg Res 111 91-9

[38] Patel S, Leal A D and Gorski D H 2005 The homeobox gene Gax inhibits angiogenesis through inhibition of nuclear factor-kappaB-dependent endothelial cell gene expression. Cancer Research 65 1414-24
[39] Zhang H and Bradley A 1996 Mice deficient for BMP2 are nonviable and have defects in amnion/chorion and cardiac development. Development 122 2977-86

[40] Dhore C R, Cleutjens J P, Lutgens E, Cleutjen̂s K B, Geusens P P, Kitslaar P J, Tordoir J H, Spronk H M, Vermeer C and Daemen M J 2001 Differential expression of bone matrix regulatory proteins in human atherosclerotic plaques. Arterioscler Thromb Vasc Biol 21 1998-2003

[41] Vogt B A, Alam J, Croatt A J, Vercellotti G M and Nath K A 1995 Acquired resistance to acute oxidative stress. Possible role of heme oxygenase and ferritin. Lab Invest 72 474-83

Wagener F A, da Silva J L, Farley T, de Witte T, Kappas A and Abraham N G 1999 Differential effects of heme oxygenase isoforms on heme mediation of endothelial intracellular adhesion molecule 1 expression. Journal of Pharmacology and Experimental Therapeutics 291416 23

Józkowicz A, Huk I, Nigisch A, Weigel G, Dietrich W, Motterlini R and Dulak J 2003 Heme oxygenase and angiogenic activity of endothelial cells: Stimulation by carbon monoxide and inhibition by tin protoporphyrinIX Antioxid Redox Signal 5 155-62

Bussolati B and Mason J C 2006 Dual role of VEGFinduced heme-oxygenase-1 in angiogenesis. Antioxidants \& Redox Signaling 8 1153-63 Stocker R and Perrella M A 2006 Heme oxygenase-1: a novel drug target for atherosclerotic diseases? Circulation 114 2178-89

Ali F, Zakkar M, Karu K, Lidington E A, Hamdulay S S, Boyle J J, Zloh M, Bauer A, Haskard D O, Evans P C and Mason J C 2009 Induction of the cytoprotective enzyme heme oxygenase- 1 by statins is enhanced in vascular endothelium exposed to laminar shear stress and impaired by disturbed flow. Journal of Biological Chemistry 284 18882-92

[47] Smith C W 2008 3. Adhesion molecules and receptors Journal of Allergy and Clinical Immunology 121

[48] McEver R P and Zhu C 2010 Rolling cell adhesion. Annu. Rev. Cell Dev. Biol. 26 363-96

Chase S D, Magnani J L and Simon S I 2012 E-selectin ligands as mechanosensitive receptors on neutrophils in health and disease. Annals of Biomedical Engineering $\mathbf{4 0}$ 849-59

[50] Meadows S M, Myers C T and Krieg P A 2011 Regulation of endothelial cell development by ETS transcription factors. Seminars in Cell \& Developmental Biology 22 976-84 
Feng W, Xing D, Hua P, Zhang Y, Chen Y-F, Oparil S and Jaimes E A 2010 The transcription factor ETS-1 mediates proinflammatory responses and neointima formation in carotid artery endoluminal vascular injury. Hypertension 55 1381-8

[52] Giridharan S and Srinivasan M 2018 Mechanisms of NF$\kappa \mathrm{B}$ p65 and strategies for therapeutic manipulation. $J$ Inflamm Res 11 407-19

[53] Liu T, Zhang L, Joo D and Sun S-C 2017 NF-кB signaling in inflammation. Signal Transduct Target Ther 2

[54] Wang M, Li J, Cai J, Cheng L, Wang X, Xu P, Li G and Liang X 2020 Overexpression of MicroRNA-16 Alleviates Atherosclerosis by Inhibition of Inflammatory Pathways. BioMed Research International 2020 8504238-12

[55] Zheng B, Yin W-N, Suzuki T, Zhang X-H, Zhang Y, Song L-L, Jin L-S, Zhan H, Zhang H, Li J-S and Wen JK 2017 Exosome-Mediated miR-155 Transfer from Smooth Muscle Cells to Endothelial Cells Induces Endothelial Injury and Promotes Atherosclerosis. Mol. Ther. 25 1279-94

[56] Bras J P, Silva A M, Calin G A, Barbosa M A, Santos S G and Almeida M I 2017 miR-195 inhibits macrophages pro-inflammatory profile and impacts the crosstalk with smooth muscle cells. ed G Pintus PLoS ONE 12 $\mathrm{e} 0188530$

[57] Chistiakov D A, Sobenin I A, Orekhov A N and Bobryshev Y V 2015 Human miR-221/222 in Physiological and Atherosclerotic Vascular Remodeling. BioMed Research International 2015 354517-8 